\title{
Positive Thinking as Training program to Developing environment working in Hospitality Industry
}

\author{
Alfatma Fatehalla Salama Ali* \\ *Lecturer of Hotel Management Department, \\ Faculty of Tourism and Hotel, \\ Minia University, Egypt
}

\begin{abstract}
This paper aims at investigating management communication strategies to find a new practical method that guarantees respect between our self and teamwork to create a healthy working environment and achieve satisfaction and thus improve the level of performance.

The sample was chosen from a group of hotels belonging to a global management. It implements a group of cognitive exercises that focus on the individual self-development and a group of independent hotels that are not interested in that direction. The measurement was measured by a scale of positive thinking as an effective tool and an interview with HR managers and head training department. The sample was 122 workers out of a total of 296 $(45 \%)$.
\end{abstract}

Findings- There is no training programs that focus on individuals and their mindsets except for the hotel chains, and they come in the second place due to the low cost.

Research limitations/implication -This study is considered as a first step to measure the importance of positive thinking among the employees of the hospitality institutions and to increase the satisfaction of the work group and improve the performance to create a healthy work environment for the future.

Keywords: positive thinking, energy power, communication.

\section{Introduction}

Positive thinking is a self-help method that has been applied to the areas of mental health, business, religion, and athletic performance. Positive thinking promises much and has reached a vast audience. Stame (2014) confirmed that positive thinking is at the core of individuals' confidence in their future. $\mathrm{He}$ described positivity as a general dispositional determinant of subjective state of health and happiness, which operates much like a trait and may account for individual variation and stability in happiness despite environmental change. Alsaleh and Kubitary (2016) referred to positivity as a propensity to assess aspects of life in general as good. How to have constant energy and effective positive energy on body health and create communication tools between people. 
The importance of research came from the hardships and difficulties imposed by the political and economic reality and their painful effects. We cannot disregard or minimize the hardships and sufferings of the world, neither do I allow them to dominate. You can allow obstacles to control your mind to the point where they are uppermost and therefore become the dominating factors in your thought pattern. By learning how to cast them from the mind, by refusing to become mentally subservient to them, and by channeling spiritual power through you, I shall outline that drawbacks are simply not permitted to destroy your happiness and wellbeing (Wong et al ,2013).

This research provides a measure and analysis of the thinking methods and attitudes of the workers in the hospitality industry to emphasize the importance of training methods and support the human element in no less important than the training needs of the work itself. Perhaps we are able to change how we think about our job to better our job satisfaction. Understanding what encourages you in your work can help you reframe your expectations and make selections to increase your satisfaction. Adapt to put stress in its place Book (2014) reported that "changing your standards or expectations, is one of the best ways to handle stress. To work on adapting, adjust your expectations.

By choosing to adopt a positive view of life, you can begin to shift out of a negative state of mind and see life as filled with possibilities and solutions instead of worries and hurdles (Dawson et al, 2015).

\section{Theories Related to Learning and Higher Order Thinking Skills}

According to Abo-Anour and Ahmad(2014), who described Lewin, K and Dewey Theory "it as a sequenced series of events, this productive process moves from reflection to inquiry, then to critical thinking processes that, in turn, leads to a "conclusion that can be substantiated" by more than personal notions and images. Thought can straighten out participations, clear mysteries, resolve confusion, unify disparities, answer questions, define problems, solve problems, reach goals, guide inferences, shape predictions, form judgments, assist decisions, and end controversies. Thinking does not occur spontaneously but must be "evoked" by "problems and questions" or by "some perplexity, confusion or doubt." The inspections or "data at hand cannot supply the solution; they can only suggest it" Al-Masry and Amer (2014)

\section{Research Objectives}

The search paper aims to explore other methods to use between the managers and employees as a basic in training the HR in hotels to guide all persons how to deal with others.

\section{Hypotheses}

1. Positive thinking affects the level of performance of the service provided to the customer and increases the production rate.

2. Negative thinking leads to higher rate of problems and obstructed solutions with the high turnover rate of employees of HR. 
3. The absence of hotel management to adopt the concept of human development priority (positive thinking) in the training programs.

4. Positive thinking leads to the creation of positive energy which creates an ideal and healthy work environment for individuals.

\section{The Problems of Hospitality}

All training programs in hotel management talk about skills instruction and information but there are not any programs that deal with our minds and try to change our thinking about thing and person. Negative thinking leads to the lack of teamwork relationship.

\section{Review}

A major recommendation for people chasing happiness has been that they need to develop positive thinking and decrease their tendency for negative thinking Peale (2008). It was confirmed by many experiments that developing the positive thinking leads to job satisfaction and creativity or rather it is the core and the starting point of both of them. Also Bogardos defined psychological direction as a " tendency with or against the environmental factors, and it has a positive or negative value (Alsokary and Alansari, 2004; Esawi, 2006).

At the same time, due to an increasingly competitive business environment, organizations need to become creative organizations in order to develop their products and services through building an organizational environment that encourages creativity and positive thinking appears as an important tool to reduce competitive pressure by solving problems to overcome external threats Trnka and Parma(2015). Success in organizations is more dependent on creativity and innovation than ever Wong et al (2013) as they need to find new methods and products, increase motivation and job satisfaction, maximize efficiency and strategic thinking at all levels, teamwork, and have a greater focus on internal customer satisfaction creativity and positive thinking seek new solutions to product problems, are related to the high levels of job satisfaction and found positive relationships between both types of reliance on subordinates and leaders encouraging subordinates to be creative. That indicated that intrinsic motivation (positive thinking) mediates the relationship between certain antecedents and readiness to take risks to creativity, and this willingness mediates the impact of essential motivation on employee creativity.

According to Patterson et al (1993) People who give priority to collective or self-transcendent values tend to display higher intentions to get involved in pro-environmental behavior than people who give priority to individual or self -enhancement values Sheehan(2014).

On the other hand the effect of being positive deepens the relation between positive self -concept and job performance. Avolio and Gardner (2005) most managers would probably agree that positivity is something they cherish in employees. Yet selection research has virtually disregarded the relation between employees' positivity and job performance. 
The researchers suggest that a broad personality characteristic, labeled positive self-concept or core self-assessments, is a potentially valuable personality trait in the prediction of job performance. Positive self -concept consists of four specific traits PREVIOUSLY STUDIED IN ISOLATION: self-esteem, generalized self-efficacy, locus of control, and (low) neuroticism or emotional stability. Drawing from four motivation theories, we argue that the main reason positive self-concept is connected with job performance is because positive employees are more motivated to perform their jobs (Kennedy and White, 1997; MacLeod and Conway ,2007).

Diener et al (2009); Rodgers et al (2010); Fredrickson (2013) confirmed that positive emotions play an outstanding role in keeping and promoting flourishing mental health. High arousal positive emotions are stronger predictors of life satisfaction among sensation seekers than among nonsensation seekers, on weekends than on weekdays, and when the concept "excitement" is experimentally primed than when the concept "peace" is primed. Several studies have replicated these results. Indeed, some have illustrated that employees who report higher levels of satisfaction maintain they are able to deliver excellent service Tracey and Tews (1995) appear to be the first to connect employee attitudes and customer satisfaction levels with intentions and behaviors. In brief, they found that organizational climate appraisals were strongly linked to an underlying emotional response, which was strongly linked to coping responses or intentions; intentions were moderately related to behavior (customer satisfaction) Tsutsui and Fujiwara( 2015). This study provides support for the commonly expressed claim that "customer orientation" should begin at the top with full management support of customer service efforts required to provide quality service to the customers.

Another problem which may arise is that the training is inappropriate. That is, training programs may focus on areas which increase productivity or efficiency, but not personal behaviors.

\section{Training programs}

\section{1- Soft skills(mental skills)}

\section{2- Hard skills}

Training is directly related to the skills, loss of capital knowledge, and policies necessary to do a particular job. It can include teaching staff members new skills, introducing them to untraditional ideas, giving them the opportunity to practice and get feedback on particular techniques or styles of working with people, or simply motivating them to discuss their work with one another. And it can, and should, be ongoing throughout a staff member's employment Truss et al (1997).

Diener et al (2009) reported that the advancement and carrying out quality management training programs can be considered the only important intervention that could have led to higher employee satisfaction and lower turnover rate. 
This paper aims to favors staffs to develop their mental skills and help them achieve higher performance standards. Furthermore, Franke (2015) clarified that pathways of thinking seem to be more likely to be reactive to systematic intervention efforts, such as objective and directed thinking training.

Training programs favors new staff as they learn the ropes of their position and help veteran staff stay updated in their field. It is essential to develop a training program that meets the needs of both staff members and the organization, and keeps the organization developing and changing for the better Lee et al (2014).

Optimistic people are much less probably to die of heart attacks than pessimists, controlling for all known physical risk factors Positive emotion reduces at least some racial biases Gable et al (2004). How people celebrate happy events that happen to their spouse is a better predictor of future love and commitment than how they respond to sad events (Giltay et al, 2004; Seligmana et al, 2009; Çetintaş et al, 2016). The positive psychology program increased person reports of enjoyment, fulfillment and involvement in work.

Wellington (2005) describes the soft skills of success referring to his experiences in different management positions, basically within human resources. Successful managers who were promoted had both excellent technical and soft skills, especially the readiness and ability to work positively with others. Cobanoglu et al (2006) concluded that soft or mental skills were among the most important skills in the job requirements for a hotel information technology manager: Communication was the most prominent, followed by critical thinking, and then the knowledge of information technology. The research for the 21st century shows that potential Book (2014) reported that "changing your standards or expectations, is one of the best methods to deal with stress. To work on adapting, adjust your expectations.

Wilson (2004) the training had made her feel more confident and motivated to achieve. In the past, all studies defined training as tool of developing our skills and teaching us the use of new technology or it is a tool of gaining customers and increasing production. However, this study goes further with training to focus on changing employees' mindset and thinking in order to become more positive in terms of what affects work so that a healthy environment can be created and quality of work increases.

According to Kafi (2016) training focuses on both skills and direction which is the core of this study. Direction handles opinions and attitudes of staff to positively change them. Alaqi( 2000); Alqahtani (2001); Esawy( 2006) referred to the fact that highly motivated employees make more positive relationships inside their organizations leading to more harmony and less stress at work.

\section{Methodology}

\section{Study Sample}

The study was carried out based on a sample of some international hotel management companies such as Four-season, Meridian and Starwood which pay great attention to the soft skills training programs. 
The sample also included other 4 and 5-star hotels that pay attention only to the training which focuses on the good of the organization. A form of "positive thinking assessment" was handed to 296 employees at the hotels, and 122 forms were good to analyze. The others were through an interview with the human resource and training managers so as to know the types of training delivered to the employees and the extent to which they focus on developing their human resource.

\section{Data collection instrument}

The interview included a number of questions from which the researcher could identify the points or the data that support the research and highlight the benefit of developing "positive thinking" and how it can affect the performance and creating a healthy work environment. In addition, they help in setting the training plan and follow its effect on the quality of work, employees and the trainers themselves. Measuring the managers' awareness of the advantages of such trainings and how they see them is something to consider as well.

For the scale of the positive thinking, a scale of one of the psychological studies centers was adopted after some modifications in terms of the number of questions. The scale was given to four academic experts; two in hotels and two in psychology to confirm the applicability of the scale. The scale includes 7 parts; answers are to be given according to Likert scale Faied and shehata (2014) .

\section{Statistical analysis}

SPSS the statistical program

- ANOVA for analyzing one-track discrepancy in more than two groups.

- Cheve test. for defining the direction of discrepancies, following ANOVA

-Tests $\mathrm{T}$ for discrepancies between the two groups.

- Confidence limits.

1-The repeat of the answers (Agree / Sometimes / Disagree) was measured in the sample.

2-Relative weights were given for every alternative of the previous four ones, and they were $(3,2,1)$ respectively.

3 -The result of multiplication of the repeats of each phrase was added for getting the overall score.

4-the average of response to each phrase was measured through equation.

With this final step, we can obtain the average response of each phrase in the survey, which helps in specifying the degree of each phrase. If the average is big, then the phrase comes true with a big degree in the light of the limits of confidence; highest or lowest and which will be clarified by the researcher later.

5-The average of the response of each phrase that comes under a specific field was added for identifying the average response of the whole field by dividing the result of the addition by the number of the phrases. It also helps in the comparison between other fields in the survey. 


\section{Guide for the scale dimensions}

\section{1-Positive expectations and optimism}

It means positively expecting gaining benefits in different aspects of personal life and being optimist about their health, social and professional life Phrases from( 1 to 8$)$.

\section{2- Self-discipline and controlling higher mental processes}

It means the skill of directing one's attention, memories and ability to imagine to the right and useful pathways that can help you cope with your surroundings socially and psychologically (9 to 20 ).

\section{3-Motivation for learning about health}

It refers to the positive tendency to change including learning new things that lead to a higher level of mental health. Those positive people believe in the effect of psychotherapy and take its instructions for granted (21 to 38).

\section{4-Positive acceptance of others}

It refers to adopting social ideas and attitudes that enable you to accept others being different from you or rather encourage such differences and be openminded (39 to 50).

\section{5-Unconditional acceptance of oneself}

It refers to being satisfied with your skills and abilities and never underestimating them in front of others. Succeeding in building healthy social relationships comes under accepting oneself as well.

Another point in the same regard is never accusing yourself of having negative qualities such as irritability, introversion, shyness or laziness. As this way of thinking impedes your development and fills you with groundless fears (51 to 67).

\section{6-Accepting personal responsibility}

Positive people are brave enough to completely shoulder their responsibilities without finding pretexts like not having enough time or others who irresponsible. That said, they are very good examples that succeed in their lives and inspire others around them (68 to 82).

\section{7-Positive risk-taking}

Positive people are more curious and always eager to explore mysterious things, so they are abler to take effective decisions and calculated risks (83 to 96).

\section{Results}

\section{Questionnaire-part one:}

The difference between the responses of the study sample " $\mathrm{N}=122$ and the relative weight and the average of the responses in the positive thinking scale. 
Table (1) Positive Expectations and optimism

\begin{tabular}{|c|c|c|c|c|c|}
\hline \multirow{2}{*}{ Statement } & \multicolumn{3}{|c|}{ Responses } & \multirow{2}{*}{$\begin{array}{l}\text { Relative } \\
\text { weight }\end{array}$} & \multirow{2}{*}{ Average } \\
\hline & Disagree & Sometimes & Agree & & \\
\hline $\begin{array}{l}\text { 1- I think that tomorrow } \\
\text { is better than today }\end{array}$ & 91 & 20 & 11 & 164.00 & 44.81 \\
\hline $\begin{array}{l}\text { 2- A great hope for the } \\
\text { future }\end{array}$ & 101 & 18 & 3 & 146.00 & 39.89 \\
\hline 3- I think I am lucky & 60 & 47 & 15 & 199.00 & 54.37 \\
\hline $\begin{array}{l}\text { 4- I think I tend to be } \\
\text { optimistic. }\end{array}$ & 88 & 27 & 7 & 163.00 & 44.54 \\
\hline $\begin{array}{l}\text { 5- I feel reassured on } \\
\text { imagining what my } \\
\text { life will be like } 10 \\
\text { years later. }\end{array}$ & 65 & 40 & 17 & 196.00 & 53.55 \\
\hline $\begin{array}{l}\text { 6- Today misfortunes } \\
\text { have benefits in the } \\
\text { future }\end{array}$ & 98 & 20 & 4 & 150.00 & 40.98 \\
\hline $\begin{array}{l}\text { 7- I think that my statas } \\
\text { always going for the } \\
\text { better }\end{array}$ & 79 & 37 & 6 & 171.00 & 46.72 \\
\hline \multirow[t]{2}{*}{$\begin{array}{l}\text { 8- I will make some } \\
\text { effort of the future } \\
\text { better than the present }\end{array}$} & 108 & 10 & 4 & 140.00 & 38.25 \\
\hline & $\begin{array}{l}\text { Mean re } \\
\text { mean resp }\end{array}$ & $\begin{array}{l}\text { tive weig } \\
\text { sse }\end{array}$ & and & 1329.00 & 45.39 \\
\hline Minimum confidence ${ }^{\wedge}=.68$ & \multicolumn{4}{|c|}{ Maximum confidence $=$} & \\
\hline
\end{tabular}

From table (1) The average of the responses of the sample in the scale of the positive thinking "Positive thinking and optimism" ranged between (38.25: 54.37) and this refers to the fact that not all phrases were applied. Also, the average of the responses of the whole part is (45.39) which means that it is not completely applied.

Table (2) The difference between the relative weight and the average in the positive thinking scale Self-discipline and controlling higher metal process

\begin{tabular}{|c|c|c|c|c|c|}
\hline \multirow{2}{*}{ Statement } & \multicolumn{3}{|c|}{ Responses } & \multirow{2}{*}{$\begin{array}{c}\text { Relative } \\
\text { weight }\end{array}$} & \multirow{2}{*}{ Average } \\
\hline & Disagree & Sometimes & Agree & & \\
\hline $\begin{array}{l}\text { 1. I love genres and songs that I have } \\
\text { to be optimistic and hope }\end{array}$ & 79 & 32 & 11 & 176.00 & 48.09 \\
\hline
\end{tabular}




\begin{tabular}{|c|c|c|c|c|c|}
\hline \multirow{2}{*}{ Statement } & \multicolumn{3}{|c|}{ Responses } & \multirow{2}{*}{$\begin{array}{l}\text { Relative } \\
\text { weight }\end{array}$} & \multirow{2}{*}{ Average } \\
\hline & Disagree & Sometimes & Agree & & \\
\hline $\begin{array}{l}\text { 2. I like songs that tend to grieve and } \\
\text { exciting Alcjn }\end{array}$ & 54 & 40 & 28 & 218.00 & 59.56 \\
\hline $\begin{array}{l}\text { 3. I can easily change the Oqkar } \\
\text { others syntactic }\end{array}$ & 79 & 33 & 10 & 175.00 & 47.81 \\
\hline $\begin{array}{l}\text { 4. I can control my feelings about } \\
\text { things, even if painful }\end{array}$ & 73 & 39 & 10 & 181.00 & 49.45 \\
\hline $\begin{array}{l}\text { 5. Human can stop himself from } \\
\text { continuing to rage }\end{array}$ & 70 & 39 & 13 & 187.00 & 51.09 \\
\hline $\begin{array}{l}\text { 6. ) Human can stop himself from } \\
\text { continuing anxiety }\end{array}$ & 50 & 43 & 29 & 223.00 & 60.93 \\
\hline 7. I think I am patient & 76 & 31 & 15 & 183.00 & 50.00 \\
\hline 8. I can control my dreams & 44 & 45 & 33 & 233.00 & 63.66 \\
\hline $\begin{array}{l}\text { 9. It controls the sudden cases of } \\
\text { stress for no reason. }\end{array}$ & 50 & 45 & 27 & 221.00 & 60.83 \\
\hline $\begin{array}{l}\text { 10. If the sound of a rose will hear } \\
\text { similarly no matter how high his } \\
\text { position. }\end{array}$ & 50 & 31 & 41 & 235.00 & 64.21 \\
\hline $\begin{array}{l}\text { 11. Never forget nor forgive someone } \\
\text { stepped on my right. }\end{array}$ & 54 & 24 & 44 & 234.00 & 63.93 \\
\hline \multirow[t]{2}{*}{$\begin{array}{l}\text { 12. Known Me I'm generally someone } \\
\text { blasts and quick to anger. }\end{array}$} & 40 & 36 & 46 & 250.00 & 68.31 \\
\hline & \multicolumn{3}{|c|}{$\begin{array}{l}\text { Mean relative weight and } \\
\text { mean response }\end{array}$} & 2516.00 & 57.29 \\
\hline Minimum confidence $=\mathbf{5 8 . 6 8}$ & \multicolumn{4}{|c|}{ Maximum confidence $=\mathbf{7 5 . 3 2}$} & \\
\hline
\end{tabular}

The difference between the responses of the study sample and the relative weight and the average of the responses in the positive thinking scale "Selfdiscipline and controlling higher metal process"

ranged between $(47.81: 68.31)$ which refers to the fact that not all the phrases were applied except for $(2,6,8,9,10,11,12)$ that were relatively applied. The average response of the whole part is (57.29) which means that the whole part was not applied.

Table (3) the difference between the relative weight and the average in

"Motivation for learning about health

\begin{tabular}{c|c|c|c|c|c}
\hline \multirow{2}{*}{ Statement } & \multicolumn{3}{|c|}{ Responses } & Relative & \multirow{2}{*}{ weight } \\
\cline { 2 - 5 } & Disagree & Sometimes & Agree & \\
\hline \hline $\begin{array}{l}\text { 1- If you get angry at myself I do not have the } \\
\text { Revolution }\end{array}$ & $\mathbf{2 7}$ & $\mathbf{3 2}$ & $\mathbf{6 3}$ & $\mathbf{2 8 0 . 0 0}$ & $\mathbf{7 6 . 5 0}$ \\
\hline $\begin{array}{l}\text { 2- I'm trying to get to know twice to avoid } \\
\text { points }\end{array}$ & $\mathbf{9 5}$ & $\mathbf{1 7}$ & $\mathbf{1 0}$ & $\mathbf{1 5 9 . 0 0}$ & $\mathbf{4 3 . 4 4}$ \\
\hline
\end{tabular}




\begin{tabular}{|c|c|c|c|c|c|}
\hline \multirow{2}{*}{ Statement } & \multicolumn{3}{|c|}{ Responses } & \multirow{2}{*}{$\begin{array}{c}\text { Relative } \\
\text { weight }\end{array}$} & \multirow{2}{*}{ Average } \\
\hline & Disagree & Sometimes & Agree & & \\
\hline 3- I can get others the chance to love me & 93 & 23 & 6 & 157.00 & 42.90 \\
\hline 4- If you fail once you will succeed next time & 97 & 19 & 6 & 153.00 & 41.80 \\
\hline 5- I do not care to know the weaknesses & 37 & 21 & 64 & 271.00 & 74.04 \\
\hline $\begin{array}{l}\text { 6- People's satisfaction too for I cannot be } \\
\text { achieved }\end{array}$ & 66 & 22 & 34 & 212.00 & 57.92 \\
\hline 7- If you fail once every time will fail & 37 & 8 & 77 & 284.00 & 77.60 \\
\hline 8 - I hope to make my life interesting & 76 & 35 & 11 & 179.00 & 48.91 \\
\hline $\begin{array}{l}\text { 9- Dull and dreary life and not for me what I } \\
\text { can do to change the situation }\end{array}$ & 35 & 35 & 52 & 261.00 & 71.31 \\
\hline $\begin{array}{l}\text { 10- People love gain but I can live without love } \\
\text { some }\end{array}$ & 59 & 29 & 34 & 219.00 & 59.84 \\
\hline $\begin{array}{l}\text { 11- Deeply troubled when I know that some } \\
\text { people hate me }\end{array}$ & 71 & 33 & 18 & 191.00 & 52.19 \\
\hline $\begin{array}{l}\text { 12- If my time is well organized and the result } \\
\text { will be different }\end{array}$ & 103 & 15 & 4 & 145.00 & 39.62 \\
\hline $\begin{array}{l}\text { 13- It's okay to feel depressed sometimes } \\
\text { human }\end{array}$ & 76 & 35 & 11 & 179.00 & 48.91 \\
\hline $\begin{array}{l}\text { 14- I am afraid of depression and avoid thinking } \\
\text { about it }\end{array}$ & 83 & 30 & 9 & 170.00 & 46.45 \\
\hline $\begin{array}{l}\text { 15- In the lower room for my growth and the } \\
\text { growth of others around me. }\end{array}$ & 79 & 32 & 11 & 176.00 & 48.09 \\
\hline $\begin{array}{l}\text { 16- That success depends on the allocation of } \\
\text { time to work and a time for fun. }\end{array}$ & 89 & 22 & 11 & 166.00 & 45.36 \\
\hline $\begin{array}{l}\text { 17- Success depends on diligent and diligence, } \\
\text { and otherwise tampered with. }\end{array}$ & 73 & 35 & 14 & 185.00 & $\mathbf{5 0 . 5 5}$ \\
\hline $\begin{array}{l}\text { 18- We can overcome what may We are afraid } \\
\text { of the concern and fears }\end{array}$ & 75 & 43 & 4 & 173.00 & 47.27 \\
\hline \multicolumn{4}{|c|}{\begin{tabular}{|l|l|l|} 
& $\begin{array}{l}\text { Mean relative weight } \\
\text { and mean response }\end{array}$ & $\mathbf{3 5 6 0 . 0 0}$ \\
\end{tabular}} & 54.04 & \\
\hline \multicolumn{6}{|c|}{ Maximum confidence $=\mathbf{7 5 . 3 2}$} \\
\hline
\end{tabular}

The average of the responses of the sample "Motivation for learning about health" ranged between (39.62: 77.60) which refers to the fact that not all the phrases were applied except for $(5,9,10)$ that were relatively applied, and $(1,7)$ were applied. The average of the whole part was $(54.04)$, that is, the part was not completely applied.

Table ( 4 ) Positive acceptance of others.

\begin{tabular}{cc|c|c|c|c|c}
\hline \hline \multirow{2}{*}{ Statement } & \multicolumn{3}{c|}{ Responses } & Relative & \multirow{2}{*}{ weight } & Average \\
\cline { 3 - 6 } & & Disagree & Sometimes & Agree & & \\
\hline \hline $\begin{array}{l}\text { 1-Usually dreamed happy } \\
\text { pleasant things }\end{array}$ & and & $\mathbf{7 5}$ & $\mathbf{3 9}$ & $\mathbf{8}$ & $\mathbf{1 7 7 . 0 0}$ & $\mathbf{4 8 . 3 6}$ \\
\hline
\end{tabular}




\begin{tabular}{|c|c|c|c|c|c|}
\hline \multirow{2}{*}{ Statement } & \multicolumn{3}{|c|}{ Responses } & \multirow{2}{*}{$\begin{array}{l}\text { Relative } \\
\text { weight }\end{array}$} & \multirow{2}{*}{ Average } \\
\hline & Disagree & Sometimes & Agree & & \\
\hline $\begin{array}{l}\text { 2- I know how to deal with people } \\
\text { no matter what I hold them in my } \\
\text { heart of distaste. }\end{array}$ & 76 & 37 & 9 & 177.00 & 48.36 \\
\hline $\begin{array}{l}\text { 3-I feel that people are free to think } \\
\text { as }\end{array}$ & 88 & 30 & 4 & 160.00 & 43.72 \\
\hline 4-Not all people think the same way. & 104 & 11 & 7 & 147.00 & 40.16 \\
\hline $\begin{array}{l}\text { 5-I feel comfortable mixing with } \\
\text { people different from me. }\end{array}$ & 71 & 35 & 16 & 189.00 & 51.64 \\
\hline $\begin{array}{l}\text { 6-I think that my view of women's } \\
\text { work liberal and unconventional. }\end{array}$ & 66 & 47 & 9 & 187.00 & 51.09 \\
\hline $\begin{array}{l}\text { 7-I think that my view of women's } \\
\text { work province and adhere to her } \\
\text { house and her children }\end{array}$ & 57 & 35 & 30 & 217.00 & 59.29 \\
\hline $\begin{array}{l}8 \text {-I love the work that requires } \\
\text { cooperation and teamwork }\end{array}$ & 88 & 29 & 5 & 161.00 & 43.99 \\
\hline $\begin{array}{l}\text { 9-I love to travel and learn about } \\
\text { foreign communities }\end{array}$ & 89 & 24 & 9 & 164.00 & 44.81 \\
\hline $\begin{array}{l}\text { 10-I find comfort in dealing with the } \\
\text { opposite sex. }\end{array}$ & 65 & 49 & 8 & 187.00 & 51.09 \\
\hline $\begin{array}{l}\text { 11-Of sound that people differ among } \\
\text { themselves }\end{array}$ & 92 & 26 & 4 & 156.00 & 42.62 \\
\hline \multirow[t]{2}{*}{$\begin{array}{l}\text { 12- Prevailing best to say that the } \\
\text { difference of opinion does not } \\
\text { spoil the intimacy }\end{array}$} & 99 & 19 & 4 & 149.00 & 40.71 \\
\hline & \multicolumn{3}{|c|}{$\begin{array}{l}\text { Mean relative weight and } \\
\text { mean response }\end{array}$} & 2071.00 & 47.15 \\
\hline Minimum confidence $=\mathbf{5 8 . 6 8}$ & \multicolumn{4}{|c|}{ Maximum confidence $=\mathbf{7 5 . 3 2}$} & \\
\hline
\end{tabular}

The average of the responses ranged between (40.16:59.29) which refers to the fact that not all the phrases were applied except for (7) that was relatively applied. The average response of the whole part is (47.15) which means that the whole part was not applied.

Table (5) The difference between the relative weight and the average in the positive thinking scale "Unconditional acceptance of oneself"

\begin{tabular}{|c|c|c|c|c|c|}
\hline \multirow{2}{*}{ Statement } & \multicolumn{3}{|c|}{ Responses } & \multirow{2}{*}{$\begin{array}{l}\text { Relative } \\
\text { weight }\end{array}$} & \multirow{2}{*}{ Average } \\
\hline & Disagree & Sometimes & Agree & & \\
\hline $\begin{array}{l}\text { 1- I do not feel any wrong practice } \\
\text { of personal pleasure, even if some } \\
\text { condemned it. }\end{array}$ & 43 & 38 & 41 & 242.00 & 66.12 \\
\hline
\end{tabular}




\begin{tabular}{|c|c|c|c|c|c|}
\hline \multirow{2}{*}{ Statement } & \multicolumn{3}{|c|}{ Responses } & \multirow{2}{*}{$\begin{array}{c}\text { Relative } \\
\text { weight }\end{array}$} & \multirow{2}{*}{ Average } \\
\hline & Disagree & Sometimes & Agree & & \\
\hline $\begin{array}{l}\text { 2- Do not get upset if one discovered } \\
\text { that me or my work something } \\
\text { wrong. }\end{array}$ & 39 & 41 & 42 & 247.00 & 67.49 \\
\hline $\begin{array}{l}\text { 3- My job even though I have not } \\
\text { had what I was all I hoped for }\end{array}$ & 85 & 30 & 7 & 166.00 & 45.36 \\
\hline $\begin{array}{l}\text { 4- My life trivial that were not filled } \\
\text { with achievements and ambition. }\end{array}$ & 57 & 35 & 30 & 217.00 & 59.29 \\
\hline $\begin{array}{l}\text { 5- When I'm working I do not care } \\
\text { that some mistakes were made } \\
\text { here }\end{array}$ & 36 & 30 & 56 & 264.00 & 72.13 \\
\hline $\begin{array}{l}\text { 6- It does not bother me so much } \\
\text { that I could be the failure of some } \\
\text { things. }\end{array}$ & 40 & 50 & 32 & 236.00 & 64.48 \\
\hline $\begin{array}{l}\text { 7- } \begin{array}{l}\text { Not necessarily the most } \\
\text { successful in everything I do }\end{array}\end{array}$ & 62 & 39 & 21 & 203.00 & 55.46 \\
\hline $\begin{array}{l}\text { 8- It does not bother me that some } \\
\text { people find me a few of gravity }\end{array}$ & 80 & 31 & 11 & 175.00 & 47.81 \\
\hline $\begin{array}{l}\text { 9- I do not care if you accused me } \\
\text { that I have a personal looking for } \\
\text { my sake }\end{array}$ & 52 & 37 & 33 & 225.00 & 61.48 \\
\hline $\begin{array}{l}\text { 10- I can feel happy even if I found } \\
\text { out that some of the important } \\
\text { people I do not hold me love. }\end{array}$ & 56 & 38 & 28 & 216.00 & 59.02 \\
\hline $\begin{array}{l}\text { 11- I have the right to think of my } \\
\text { advantage own }\end{array}$ & 76 & 33 & 13 & 181.00 & 49.45 \\
\hline $\begin{array}{l}\text { 12- I did and do my things a lot of } \\
\text { value. }\end{array}$ & 79 & 39 & 4 & 169.00 & 46.17 \\
\hline $\begin{array}{l}\text { 13- I always feel guilt and error to } \\
\text { spoil the degree to exercise any } \\
\text { pleasures }\end{array}$ & 50 & 41 & 31 & 225.00 & 61.48 \\
\hline $\begin{array}{l}\text { 14- Isolation necessary for me } \\
\text { between now and then him. }\end{array}$ & 67 & 33 & 22 & 199.00 & 54.37 \\
\hline $\begin{array}{l}\text { 15- I can accept self without } \\
\text { complaint }\end{array}$ & 74 & 40 & 8 & 178.00 & 48.63 \\
\hline $\begin{array}{l}\text { 16- I regret that strained or broken } \\
\text { relationship with someone I love. }\end{array}$ & 75 & 33 & 14 & 183.00 & 50.00 \\
\hline $\begin{array}{l}\text { 17- Usually I accept myself even if } \\
\text { exposed to criticize others. }\end{array}$ & 75 & 34 & 13 & 182.00 & 49.73 \\
\hline \multicolumn{3}{|c|}{\begin{tabular}{l|l} 
& $\begin{array}{l}\text { Mean relative weight and } \\
\text { mean response }\end{array}$ \\
\end{tabular}} & 3508.00 & 56.38 & \\
\hline \multicolumn{5}{|l|}{ Minimum confidence $=\mathbf{5 8 . 6 8}$} & \\
\hline
\end{tabular}

The average of the responses ranged between (45.36: 72.13) which refers to the fact that not all the phrases were applied except for $(1,2,4,5,6,9,10$, 13) that were relatively applied. The average response of the whole part is (56.38) which means that the whole part was not applied. 
Table( 6) The difference between the relative weight and the average acceptance of personal responsibility.

\begin{tabular}{|c|c|c|c|c|c|}
\hline \multirow{2}{*}{ Statement } & \multicolumn{3}{|c|}{ Responses } & \multirow{2}{*}{$\begin{array}{c}\text { Relative } \\
\text { weight }\end{array}$} & \multirow{2}{*}{ Average } \\
\hline & Disagree & Sometimes & Agree & & \\
\hline $\begin{array}{l}\text { 1- I think I am quite attentive to my } \\
\text { rights and responsibility. }\end{array}$ & 85 & 34 & 3 & 162.00 & 44.26 \\
\hline $\begin{array}{l}\text { 2- If you subscribe to perform a } \\
\text { specific job: }\end{array}$ & 70 & 38 & 14 & 188.00 & 51.37 \\
\hline $\begin{array}{l}\text { 3- If you subscribe to perform a } \\
\text { specific job I do not care and let } \\
\text { things move themselves }\end{array}$ & 41 & 25 & 56 & 259.00 & 70.77 \\
\hline $\begin{array}{l}\text { 4- Describe me my relatives that I } \\
\text { have someone responsible and } \\
\text { reliable }\end{array}$ & 82 & 32 & 8 & 170.00 & 46.45 \\
\hline $\begin{array}{ll}\text { 5- } & \text { Ask me for leadership and } \\
\text { performance of the business that } \\
\text { requires explanation and guidance }\end{array}$ & 80 & 38 & 4 & 168.00 & 45.90 \\
\hline $\begin{array}{l}\text { 6- One does not cost me only do what } \\
\text { I love to do it }\end{array}$ & 45 & 40 & 37 & 236.00 & 64.48 \\
\hline $\begin{array}{l}\text { 7- When I face a problem that I face } \\
\text { the best, and I find her solution }\end{array}$ & 96 & 17 & 9 & 157.00 & 42.90 \\
\hline $\begin{array}{l}\text { 8- When you face the problem of what } \\
\text { to discard the best and to resolve } \\
\text { themselves }\end{array}$ & 36 & 29 & 57 & 265.00 & 72.40 \\
\hline $\begin{array}{l}\text { 9- According to the prevailing } \\
\text { prisoner to say that "we are all } \\
\text { responsible for the completion of } \\
\text { the work and complete it }\end{array}$ & 89 & 23 & 10 & 165.00 & 45.08 \\
\hline $\begin{array}{l}\text { 10- A prisoner in my life in accordance } \\
\text { with the prevailing say, "I am } \\
\text { responsible for what I do but I am } \\
\text { not responsible for what others are } \\
\text { doing." }\end{array}$ & 60 & 38 & 24 & 208.00 & 56.83 \\
\hline $\begin{array}{l}\text { 11- In the event of default in a } \\
\text { collective action responsible for } \\
\text { this failure and look for a solution }\end{array}$ & 90 & 25 & 7 & 161.00 & 43.99 \\
\hline $\begin{array}{l}\text { 12- In the event of default in a } \\
\text { collective work of the group and it } \\
\text { is the responsibility they face }\end{array}$ & 76 & 30 & 16 & 184.00 & 50.27 \\
\hline $\begin{array}{l}\text { 13- It does not take place for success in } \\
\text { life perseverance and personal } \\
\text { effort even if we did not get what } \\
\text { we want immediately. }\end{array}$ & 91 & 21 & 10 & 163.00 & 44.54 \\
\hline \multirow[t]{2}{*}{$\begin{array}{l}\text { 14- Success cannot be achieved in life } \\
\text { generally only if there is a strong } \\
\text { person to help us do so. }\end{array}$} & 62 & 47 & 13 & 195.00 & 53.28 \\
\hline & \multicolumn{3}{|c|}{$\begin{array}{l}\text { Mean relative weight and } \\
\text { mean response }\end{array}$} & 2681.00 & 52.32 \\
\hline "Minimum confidence $=\mathbf{5 8 . 6 8}$ & \multicolumn{4}{|c|}{ Maximum confidence $=\mathbf{7 5 . 3 2}$} & \\
\hline
\end{tabular}


The average of the responses ranged between (42.90:72.40) which refers to the fact that not all the phrases were applied except for $(3,6,8)$ that were relatively applied. The average response of the whole part is (52.32) which means that the whole part was not applied.

Table (7) The difference between the relative weight and the average in Positive risk-taking.

\begin{tabular}{|c|c|c|c|c|c|}
\hline \multirow{2}{*}{ Statement } & \multicolumn{3}{|c|}{ Responses } & \multirow{2}{*}{$\begin{array}{l}\text { Relative } \\
\text { weight }\end{array}$} & \multirow{2}{*}{ Averag } \\
\hline & Disagree & Sometimes & Agree & & \\
\hline $\begin{array}{l}\text { 1- My life is heading for the better } \\
\text { because of my endurance risk and not } \\
\text { to give in life }\end{array}$ & 63 & 46 & 13 & 194.00 & 53.01 \\
\hline $\begin{array}{l}\text { 2- I was always more than one way to get } \\
\text { things done. }\end{array}$ & 69 & 45 & 8 & 183.00 & 50.00 \\
\hline $\begin{array}{l}\text { 3- Successful leader is risking to take the } \\
\text { appropriate decision in the lack of } \\
\text { complete information }\end{array}$ & 71 & 26 & 25 & 198.00 & 54.10 \\
\hline $\begin{array}{l}\text { 4- Leader does not act, but what is true } \\
\text { even avoids the dangers and risks }\end{array}$ & 91 & 22 & 9 & 162.00 & 44.26 \\
\hline $\begin{array}{l}\text { 5- Most people are creative and attractive } \\
\text { to me in Different opinions and ideas }\end{array}$ & 72 & 40 & 10 & 182.00 & 49.73 \\
\hline $\begin{array}{l}\text { 6- I like to spend a period of my life in a } \\
\text { foreign country }\end{array}$ & 51 & 39 & 32 & 225.00 & 61.48 \\
\hline $\begin{array}{l}\text { 7- I prefer to be my friends are diverse in } \\
\text { age, profession and religion }\end{array}$ & 90 & 22 & 10 & 164.00 & 44.81 \\
\hline $\begin{array}{l}\text { 8- I prefer to be my friends close to me } \\
\text { familiarly and ideologically. }\end{array}$ & 63 & 38 & 21 & 202.00 & 55.19 \\
\hline $\begin{array}{l}\text { 9- I think I succeeded because I am a } \\
\text { lover of risky and impulsive to some } \\
\text { extent. }\end{array}$ & 63 & 39 & 20 & 201.00 & 54.92 \\
\hline $\begin{array}{l}\text { 10- I think I succeeded because I do not I } \\
\text { act only after reflection and } \\
\text { contemplation of the consequences }\end{array}$ & 84 & 33 & 5 & 165.00 & 45.08 \\
\hline $\begin{array}{l}\text { 11- When I am experiencing difficulty } \\
\text { gone act what is appropriate, even if it } \\
\text { were not a good result }\end{array}$ & 83 & 33 & 6 & 167.00 & 45.63 \\
\hline $\begin{array}{l}\text { 12- When I face the difficulty of waiting } \\
\text { to consult me who they know about it }\end{array}$ & 89 & 27 & 6 & 161.00 & 43.99 \\
\hline $\begin{array}{l}\text { 13- I like to work that allows me the } \\
\text { freedom of thinking and decision } \\
\text { making }\end{array}$ & 92 & 25 & 5 & 157.00 & 42.90 \\
\hline \multirow[t]{2}{*}{$\begin{array}{l}\text { 14- I love the obvious and familiar } \\
\text { business }\end{array}$} & 80 & 34 & 8 & 172.00 & 46.99 \\
\hline & \multicolumn{3}{|c|}{$\begin{array}{l}\text { Mean relative weight and } \\
\text { mean response }\end{array}$} & 2533.00 & 49.43 \\
\hline "Minimum confidence $=\mathbf{5 8 . 6 8}$ & \multicolumn{5}{|c|}{ Maximum confidence $=\mathbf{7 5 . 3 2}$} \\
\hline
\end{tabular}


The average of the responses ranged between $(42.90: 61.48)$ which refers to the fact that not all the phrases were applied except for (6) that was relatively applied. The average response of the whole part is (49.43) which means that the whole part was not applied.

Table ( 8) Analysis of the one-track discrepancy in the study sample according to age in the scale of positive thinking

\begin{tabular}{|c|c|c|c|c|c|c|}
\hline The Axis & $\begin{array}{l}\text { Source of } \\
\text { contrast }\end{array}$ & $\begin{array}{l}\text { Mean } \\
\text { Square }\end{array}$ & $\begin{array}{l}\begin{array}{c}\text { Degree of } \\
\text { freedom }\end{array} \\
\end{array}$ & $\begin{array}{l}\text { Sum of } \\
\text { square }\end{array}$ & $\begin{array}{c}\text { P- } \\
\text { value }\end{array}$ & Sig \\
\hline \multirow[t]{2}{*}{$\begin{array}{l}\text { 1-Positive expectations and } \\
\text { optimism }\end{array}$} & Between Groups & 10.73 & 3 & 32.19 & \multirow{2}{*}{1.76} & \multirow{2}{*}{$\begin{array}{c}\text { Non- } \\
\text { sig }\end{array}$} \\
\hline & Within Group & 6.11 & 118 & 721.43 & & \\
\hline \multirow{2}{*}{$\begin{array}{l}\text { 2- Self-discipline and controlling } \\
\text { higher mental processes }\end{array}$} & Between & 56.41 & 3 & 169.22 & \multirow[t]{2}{*}{3.98} & \multirow{2}{*}{0.01} \\
\hline & Within & 14.17 & 118 & 1671.44 & & \\
\hline \multirow{2}{*}{$\begin{array}{l}\text { 3-Motivation for learning about } \\
\text { health }\end{array}$} & Between & 88.21 & 3 & 264.62 & \multirow{2}{*}{5.001} & \multirow{2}{*}{0.01} \\
\hline & Within & 17.64 & 118 & 2081.42 & & \\
\hline \multirow[t]{2}{*}{ 4-Positive acceptance of others } & Between & 11.13 & 3 & 33.39 & \multirow[t]{2}{*}{1.19} & \multirow{2}{*}{$\begin{array}{c}\text { Non- } \\
\text { sig }\end{array}$} \\
\hline & Within & 9.32 & 118 & 1099.54 & & \\
\hline \multirow[t]{2}{*}{$\begin{array}{l}\text { 5-Unconditional acceptance of } \\
\text { oneself learning about health }\end{array}$} & Between & 158.81 & 3 & 476.43 & \multirow{2}{*}{6.41} & \multirow[b]{2}{*}{0.01} \\
\hline & Within & 24.78 & 118 & 2924.19 & & \\
\hline \multirow{2}{*}{$\begin{array}{l}\text { 6-Accepting personal } \\
\text { responsibility }\end{array}$} & Between & 126.07 & 3 & 378.22 & \multirow[t]{2}{*}{10.44} & \multirow{2}{*}{0.01} \\
\hline & Within & 12.07 & 118 & 1424.71 & & \\
\hline \multirow[t]{2}{*}{ 7-Positive risk-taking } & Between & 34.83 & 3 & 104.47 & \multirow{2}{*}{2.18} & \multirow{2}{*}{$\begin{array}{l}\text { Non- } \\
\text { sig }\end{array}$} \\
\hline & Within & 15.98 & 118 & 1885.63 & & \\
\hline \multirow{2}{*}{ Total } & $\begin{array}{l}\text { Between } \\
\text { Groups }\end{array}$ & 2449.68 & 3 & 7349.05 & \multirow{2}{*}{8.54} & \multirow{2}{*}{0.01} \\
\hline & $\begin{array}{l}\text { Within } \\
\text { Groups }\end{array}$ & 286.83 & 118 & 33845.67 & & \\
\hline
\end{tabular}

There are indicative discrepancies at the level (0.01) in the study sample according to age in the scale of positive thinking (self-discipline and controlling higher mental process, motivation for learning about health, Unconditional acceptance of oneself, acceptance of personal responsibility, the overall score of the scale) which means that one of the tests must be used for specifying the direction of such discrepancies. That said, the researcher is going to use Cheve test for that. On the other hand, there are non-indicative at the level of $(0.01)$ in the sample according to age in the scale of positive thinking (positive expectations and optimism, positive acceptance of others, positive risk-taking). 
Table( 9) Cheve test in the study sample according to age in the parts having statistically indicative discrepancies in the scale of positive thinking

\begin{tabular}{|c|c|c|c|c|c|c|c|}
\hline Verbal & Age & $\mathbf{N}$ & Average & $20-30$ & $31-40$ & $41-50$ & $\begin{array}{c}\text { More } \\
\text { than 50 }\end{array}$ \\
\hline \multirow{4}{*}{$\begin{array}{l}\text { 1- Positive } \\
\text { expectations } \\
\text { and optimism }\end{array}$} & $20-30$ & 47 & 21.19 & - & 0.01 & 1.27 & $4.56^{*}$ \\
\hline & $31-40$ & 41 & 21.20 & & - & 1.28 & $4.57^{*}$ \\
\hline & 41-50 & 26 & 19.92 & & & - & 3.29 \\
\hline & $\begin{array}{c}\text { More } \\
\text { than } 50\end{array}$ & 8 & 16.63 & & & & - \\
\hline \multirow{4}{*}{$\begin{array}{l}\text { 2- "Motivation for } \\
\text { learning about } \\
\text { health }\end{array}$} & $20-30$ & 47 & 30.47 & - & 1.23 & 2.35 & $5.72^{* * *}$ \\
\hline & $31-40$ & 41 & 29.24 & & - & 1.12 & 4.49 \\
\hline & 41-50 & 26 & 28.12 & & & - & 3.37 \\
\hline & $\begin{array}{c}\text { More } \\
\text { than } 50\end{array}$ & 8 & 24.75 & & & & - \\
\hline \multirow{4}{*}{$\begin{array}{l}\text { 3- Unconditional } \\
\text { acceptance of } \\
\text { oneself }\end{array}$} & $20-30$ & 47 & 30.60 & - & 1.50 & $4.45^{* * *}$ & $5.97^{*}$ \\
\hline & $31-40$ & 41 & 29.10 & & - & 2.95 & 4.47 \\
\hline & $41-50$ & 26 & 26.15 & & & - & 1.52 \\
\hline & $\begin{array}{l}\text { More } \\
\operatorname{than} 0 .\end{array}$ & 8 & 24.63 & & & & - \\
\hline \multirow{4}{*}{$\begin{array}{l}\text { 4- } \text { Accepting } \\
\text { personal } \\
\text { responsibility }\end{array}$} & $20-30$ & 47 & 22.66 & - & 0.80 & $3.12^{* * *}$ & $4.41^{*}$ \\
\hline & $31-40$ & 41 & 23.46 & & - & $3.92^{* * *}$ & $5.21^{* * *}$ \\
\hline & $41-50$ & 26 & 19.54 & & & - & 1.29 \\
\hline & $\begin{array}{c}\text { More } \\
\text { than 50 }\end{array}$ & 8 & 18.25 & & & & - \\
\hline \multirow{4}{*}{ Total } & $20-30$ & 47 & 154.53 & - & 1.73 & $14.65^{* * *}$ & $25.40^{* * \pi}$ \\
\hline & $31-40$ & 41 & 152.80 & & - & $12.92^{*}$ & $23.67^{* * 3}$ \\
\hline & 41-50 & 26 & 139.88 & & & - & 10.75 \\
\hline & $\begin{array}{c}\text { More } \\
\text { than } 50\end{array}$ & 8 & 129.13 & & & & - \\
\hline
\end{tabular}

Table (10) T tests for indicative discrepancies in the study sample according to the type of training in the scale of positive thinking

\begin{tabular}{|c|c|c|c|c|c|c|}
\hline \multirow{3}{*}{ The Axis } & \multirow{2}{*}{\multicolumn{2}{|c|}{$\begin{array}{c}\text { soft skills training } \\
\mathrm{N}=53\end{array}$}} & \multirow{2}{*}{\multicolumn{2}{|c|}{$\begin{array}{c}\begin{array}{c}\text { hard skills } \\
\text { training }\end{array} \\
\mathrm{N}=69 \\
\end{array}$}} & \multirow{3}{*}{$\begin{array}{c}\text { T- } \\
\text { value }\end{array}$} & \multirow{3}{*}{ sig } \\
\hline & & & & & & \\
\hline & Hotels & $\begin{array}{l}\text { Chain } \\
\text { Hotels }\end{array}$ & Hotels & $\begin{array}{l}\text { Chain } \\
\text { hotels }\end{array}$ & & \\
\hline $\begin{array}{c}\text { Positive expectations } \\
\text { and optimism }\end{array}$ & 2.78 & 11.75 & 2.03 & 10.23 & 3.49 & 0.01 \\
\hline $\begin{array}{l}\text { 2- Self-discipline and } \\
\text { controlling higher mental } \\
\text { processes }\end{array}$ & 3.68 & 21.19 & 4.03 & 20.19 & 1.41 & $\begin{array}{l}\text { Non- } \\
\text { sig }\end{array}$ \\
\hline $\begin{array}{l}\text { 3- Motivation for learning } \\
\text { about health }\end{array}$ & 4.21 & 30.08 & 4.46 & 28.49 & 1.99 & 0.05 \\
\hline 4- Positive acceptance of & 3.00 & 17.70 & 3.01 & 16.42 & 2.33 & 0.05 \\
\hline
\end{tabular}




\begin{tabular}{l|c|c|c|c|c|c}
\hline \hline \multicolumn{1}{c|}{ others } & & & & & & \\
\hline $\begin{array}{l}\text { 5-Unconditional } \\
\text { acceptance of oneself } \\
\text { learning about health }\end{array}$ & $\mathbf{5 . 2 6}$ & $\mathbf{2 9 . 4 3}$ & 5.31 & $\mathbf{2 8 . 2 3}$ & $\mathbf{1 . 2 4}$ & $\begin{array}{c}\text { Non- } \\
\text { sig }\end{array}$ \\
\hline $\begin{array}{l}\text { 6- Accepting personal } \\
\text { responsibility }\end{array}$ & $\mathbf{3 . 4 6}$ & $\mathbf{2 2 . 0 6}$ & 4.17 & $\mathbf{2 1 . 9 1}$ & $\mathbf{0 . 2 0}$ & $\begin{array}{c}\text { Non- } \\
\text { sig }\end{array}$ \\
\hline 7- Positive risk-taking & $\mathbf{4 . 3 4}$ & $\mathbf{2 1 . 6 4}$ & 3.71 & $\mathbf{2 0 . 0 9}$ & $\mathbf{2 . 1 3}$ & $\mathbf{0 . 0 5}$ \\
\hline Total & $\mathbf{1 7 . 4 5}$ & $\mathbf{1 5 3 . 8 5}$ & 18.51 & $\mathbf{1 4 5 . 5 6}$ & $\mathbf{2 . 5 1}$ & $\mathbf{0 . 0 5}$ \\
\hline \hline
\end{tabular}

There are indicative discrepancies at the level $(0.01,0.05)$ in the sample according to the type of training (Positive expectations and optimism, motivation for learning about health, positive risk-taking) supporting the sample (soft skills training)

Interview questionnaire-part two: human resource department and type of training programs to development staffs soft skills and hard skills: personal and professional skills. Skip to main content, the interview questions and their answers:

- The training programs given by Four-season, Marriot, Starwood and the effect of soft skills training on the quality of work and the psychological and social sides of workers.

- Training needs analysis: every hotel management studies the required skills and identifies the targeted staff for training and to what extent do they expect they will respond.

- The training department collects the training needs and works on categorizing, analyzing them and consequently setting the priorities of giving them. It also secures the trainers; internal and external, sets the most suitable training timetables and the assessment tools.

- The plan is put based on the last year's results (from October to December) for setting the agenda and budget of the year.

- Orientation training is given according to the interviews. The high rate of turnover requires more training. According to managers, most training programs are obligatory and some are optional but they should be attended once at any branch. Some examples are service culture - self-treatment customer service - loyalty - dealing with workmates - team playing setting objectives -work pressures.

- The outcome of training and workers' improvement course:

- The outcome varies according to the level of education and the ability to grasp information. One of the managers at Marriot clarified that the previously mentioned trainings has a great impact on new employees by $100 \%$ as against experienced employees who are not affected by such trainings as they are used to a certain type of work, and training for them is 
a waste of time. Such assumption is confirmed through the results that said that ages from 20 to 30 and from 31 to 40 are more responsive to teaching positive thinking than those who 50 or older. This means that the positive thinking training is essential to new workers and increases their loyalty to their organizations and their resilience and obedience at work. this agreed with opinion during interview and reported Mohsen(2016).

\section{The priority of training programs:}

- First aid - Distinguishing fires

- Professional training at each department, and then comes the programs that target individuals and handle their work issues such as work pressure, human needs and positive thinking.

- Why are the psychological and social sides not given priority in training?

- It was put quite straightforwardly that the budget is the main reason behind giving less attention to

- Emphasizing the positive thinking and its role in improving quality of work and creating healthy environment" What do you think of such emphasis and its role in work and how is it reflected on the employees' recovery from diabetes blood pressure and illnesses?

- The effect of positive thinking on work environment: Do these training programs on team work, work pressures and time management which focus on the psychological and social sides, have a positive effect on team building and the relation of people with each other?

- They do positively affect employees psychologically and change their way of thinking which becomes noticeable in the staff's attitudes and satisfaction it is agree with Machouche et al (2012).

- In addition to assessing the training content, there is an assessment of trainers and the outcome of the training. As for training managers (fast tracking), the headquarters takes care of that and sometimes it lasts for a complete year. Not all companies fulfill their promises of promotions, the thing that backfires on the response to training and causes employees to lose their loyalty to the organization.

- Which categories of employees should be trained on positive thinking?

-All managers emphasized that all levels; low, mediate and upper should take that type of training.

-They also emphasized that young employees should feel involved and assimilated into the organization by their heads so that they do not do their work under constant censorship. 
That is what is called "sense mandatory" in the positive thinking training. Zou and Comp (2015) confirmed that young employees basically feel loyal to their companies when they are satisfied with their professional development schemes and their relations in the place.

- The supervisors should not reprimand the workers in their departments just because they themselves are reprimanded by their bosses, as it creates more pressure.

- Managers should be the first people to practice the positive thinking tips with their employees and provide them with more confidence and credibility so that they can keep their positions whose base is the quality performance of workers in a healthy environment.

\section{Discussion}

Cho and Schmelzer (2000) The targeted outcome of most training programs is that all trainees receive the same information and process it in a similar way. The outcome of the suggested differs in that it permits each trainee to process information in a slightly different, but suitable manner. Trainees would be stimulated to develop their own thinking and self-management skills which could empower them to plan or construct their individual understanding of the content. As each learner communicates his/her understanding to others, there would be an increased level of peer and group interaction. This could, in turn (training), cause a more cooperative social structure inside the workplace, as well as bettered relations with the external customer. This freedom of thinking and flexibility would help managers to be more creative in how they deal with situations that are new and challenging job .Caprara et al (2012); Robles and keep (2012).

The results have proved that positive thinking plays an extremely important role in(self-discipline and controlling higher mental processes, motivation for learning about health, unconditional acceptance of oneself, acceptance of personal responsibility) and that it can be expected how positive people perform their jobs(according to Avolio and Gardner (2005) Kennedy and White, (1997)

The study has proved that there is a statistical indication in relation with the impact of positive expectations and optimism on people's different aspects of life and their expectations of having positive outcomes in their health, personal, social and professional lives and this agreed with Kosnes et al (2013). It is by 45,39 which means that the whole part is not applied.

\section{Motivation for learning about health:}

This refers to the positive change in connection with motivation and passion for learning new things for keeping mental health. This part was applied among young ages much more that the older ones and that was what the study came up with through interviews with training managers. 
Also it proves the supposition of the study that hotel managements do not prioritize the development of human resources (positive thinking) in their training programs or the soft skills, which is the objective of this study.

For long-serving staff, a positive thinking training program has a lot of benefits:

- It helps them to become continually more competent at what they do.

- It grows their knowledge of the field by exposing them to the latest research and theory, and can expose them to new ideas which eventually may improve their own effectiveness and that of the organization.

- By preventing them from becoming bored and stale, it helps them to keep interest in and passion for their work.

- It can expose them to other performers.

- with varied -- and perhaps better -- methods.

- It provides them with one more reason to continue with the organization.

- It keeps the organization as a whole dynamic: growing, thinking and changing. A dynamic organization is almost always a healthy and effective one.

In brief, a good continuous training program for all staff increases organizational efficacy and keeps it increasing, rather than allowing the organization to lie dormant Mac Leod and Conway (2007).

Positive thinking leads to creating positive energy, the thing that turns workplace into healthy ideal environment for individuals (final assumption) where they are ready take responsibility and positive risks, and it is clear in the results of tables $6 \& 7$.

\section{Conclusion, recommendation and implications}

This paper aims at providing a development training programs for employees and managers in hospitality industry. The main thought of the program is about power energy efficiency. The theory of planned behavior was used as a framework for staffing mindset. Employees generally felt positive about the suggested interventions and expected that they would lead to financial savings, better the relationship between others and warmth of their place, and sense of pride in the hotel.

However, while managers planned to take up energy efficiency (positive thinking) if offered to them, they are ready to obtain high standards of performance if they just believe their employees will do it according to what they thought. The ownership and the belief in humans' ability to handle climate change were found to predict readiness to invest. These findings help to understand responses to thought as positive thinking that seek to better the energy efficiency of hotels agreed with Bakker (2008). Many see involvement as a step higher than satisfaction or encouragement at work. 
All sources define positive thinking as engagement to some degree by its results and something given by the employee which can be useful for the organization. They generally agree that engaged employees get more attached to their organization, investing themselves not only in their role, but in the organization as a whole. Boxall and Purcell (2003) Smith and Marwick (2009). Human resource in hospitality industry must believe positive thinking lead employees to engagement in a combination of attitudes, ideas and conducts that relate to satisfaction, advocacy, commitment, pride, loyalty and responsibility. Positive thinking goes beyond the more traditional concept of employee satisfaction and relates to the extent to which employees are fully involved in the company and their work'(Healthy environment).

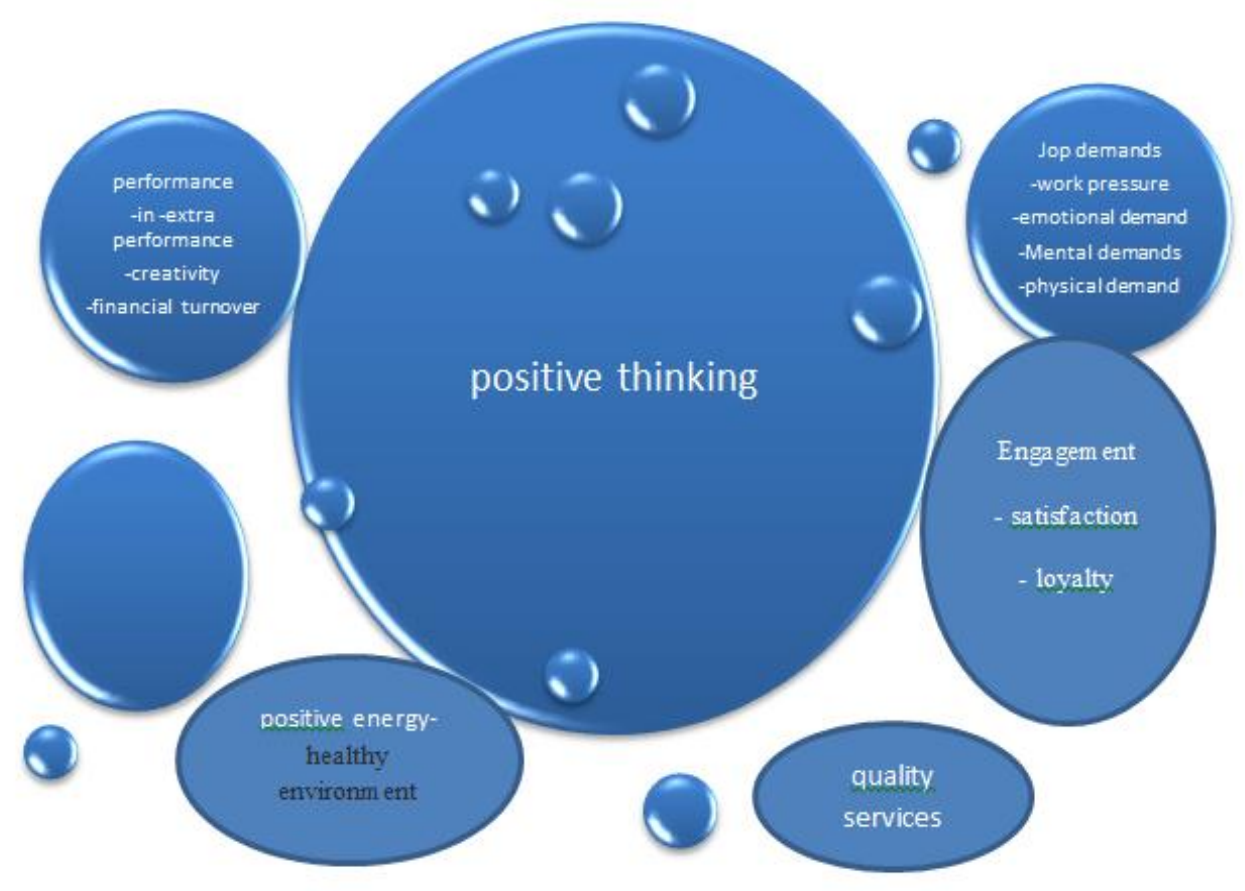

Figure (1) Impact of positive thinking of environment work in hospitality and persons health.

Positive thinking is one of the most effective methods by which we can combat work stress and burn-out. It can happen through changing the mindset and guiding persons with the help of specialists and the continuous support. (Kafi 2016)Positive thinking leads to creating positive energy at work, the thing that creates an ideal and healthy environment for employees. As a result, customers receive high quality services and employees become more loyal to the organization.

Scales of positive thinking can be used as tools for expecting the employees' performance and communicating with the fresh workers at the HR department. Finally, a training program (positive thinking) should be applied to everybody in the organization, from administrators to line staff to support staff. 
All need, and should have the opportunity, to become continually better at what they do, bettering both their own and the organization 's effectiveness Hotels should work on the positive thinking training in order to improve the quality of work by increasing the positive energy that is related to the workers' soft skills. Our mindsets are either positive or negative and each has its own effects on the individual's health, treatment and techniques of solving problems.

\section{REFERENCES}

Alsaleh, M A. and Kubitary,A.(2016)," New Frontiers in the Treatment of Mentalwar Disorders and Posttraumatic Disorder by Repeating Phrases of Positive Thoughts of Syrian refugees Populations War Victims”., Journal of Biomedical., Vol. 6 No. 1:4

AvolioT,B,J. and Gardner,W.(2005),"Authentic leadership development:Getting to the root of positive forms of leadership", Elsevier., (16) 315 - 338.

Book (2014)," Mayo Clinic Family Health Book" , 4th Edition,Volume 66, , Pages 335-349.

Boxall,P.and Purcell,J.( 2003 )," Strategy and Human Resource Management "Vol,( 57) , N( 1) Article 84 .

Bakker ,A. (2008)"Towards a model of work engagement "Career Development International Vol. 13 No. 3, pp. 209-223.

Caprara ,G.V., Alexssandri ,G., Eisenberg ,N., Kupfer ,A., Steca ,P., Caprara ,M,G., Yamaguchi ,S., Fukuzawa ,A. and Abela ,J.( 2012),'The Positivity Scale”, American Psychological Association Vol. 24, No. 3, 701-712.

Çetintaş,K., Sarıçam, H. and Oğuz,A.(2016),’Preservice Teachers' Critical Thinking Dispositions and Positive Thinking Skills Levels", Number: 413.

Cho,W. and Schmelzer ,C.(2000),"Just-in-time education: tools for hospitality managers of the future? "International Journal of Contemporary Hospitality Management.,31-36.

Cobanoglu, C., Dede, P. \& Poorani, A. (2006)," An analysis of skills and competencies of full service hotel technology managers". Journal of Teaching in Travel \& Tourism, 6(4), 19-35.

Dawson , C., Meza ,D., Henley,A. and Arabsheibani .R.(2015 ),'The Power of (Non) Positive Thinking: Self-Employed Pessimists Earn More than Optimists" No. 9.p,242

Diener, E., Wirtz, D., Tov, W., Kim-Prieto, C., Choi, D., Oishi, S. \& Biswas-Diener, R. (2009)." New measures of well-being: Flourishing and Positive and Negative Feelings"., Springer Science.

Franke ,K, B. (2015),’Pathways Thinking as a Mediator between Positive Emotions and General Life Satisfaction in Middle School Students",University of South Carolina - Columbia.

Fredrickson ,B, L. (2013),'JUpdated Thinking on Positivity Ratios University of North Carolina", .. American Psychological Association . 
Gable, E.L., Reis, H.T., Impett, E.A. \& Asher, E.R. (2004)," What do you do when things go right? The intrapersonal and interpersonal benefits of sharing positive events" Journal of Personality and Social Psychology, 87, 228-245.

Giltay, E.J., Geleijnse, J.M., Zitman, F.G., Hoekstra, T. \& Schouten, E.G. (2004),” Dispositional optimism and all-cause and cardiovascular mortality in a prospective cohort of elderly Dutch men and women"., Archives of General Psychiatry, 61, 11261135 .

Kennedy, J.R. M. and White, T. (1997)," Service provider training programs at odds with customer Requirements in five-star hotels", the journal of service marketing, vol.11.no.4.

Kosnes ,L., Whelan ,R., O’Donovan ,A., O’Donovan ,O.(2013).’Implicit measurement of positive and negative future thinking as a predictor of depressive symptoms and hopelessness" Consciousness and Cognition (22)p., 898-912.

Lee,J,J.,Moon,H,J.,Lee,K,J and Joo J,K.(2014) "Fatigue and related factors among hotel workers: the effects of emotional labor and non-standard working hours "Annals of Occupational and Environmental Medicine.,p 1-10.

MacLeod ,A. and Conway ,C.(2007)," Well-being and positive future thinking for the self versus others .,Taylor \& Francis Group21 (5), 1114-1124.

Machouche,S.T.,Benaouda,B., and Grine,F.(2012 ).“positive thinking an Islamic perspective Alshagara ., $\operatorname{vol}(17), \mathrm{N}(2$.

Mohsen,M(2016)"committed generations:a case study on generationsX and Yemployeees in Saudi hotels,Anatolia" International Journal of tourism and hospitality,.vol27 , 4 p,456-467.

Patterson,G.R.,Debaryshe,B. and Ramsey,E.(1993),'Development perspective on antisocial behavior"., American Psychological.,44.,263-271.

Peale, N. V. (2008)," The power of positive thinking". New York, Prentice Hall second addation.

Robles,M,M.(2012),'Executive Perceptions of the Top 10 Soft Skills Needed in Today's Workplace” ,Business Communication Quarterly ,75.(4). 453-465.

Rodgers,J,S., Peng,K. and Wang,L.(2010)," Dialecticism and the Co-occurrence of Positive and Negative Emotions Across Cultures"., Journal of Cross-Cultural Psychology 41(1) 109-115.

Seligmana ,M,E., Ernstb ,R,M., Gillhamc ,K,R. and Linkinsd ,M.(2009),’Positive education: positive psychology and classroom interventions" Vol. 35, No., p293-311.

Smith ,G,R.and Markwick ,C.(2009)," Employee Engagement A review of current thinking “, Institute for employment studies, Mantell Building. 
Sheehan ,M (2014),'Human resource management and performance: Evidence from small and medium-sized firm" International Small Business Journal,Vol. 32(5) 545570 .

Stame ,N.(2014),'Positive Thinking Approaches to Evaluation and Program Perspectives”, Canadian Journal ,Evaluation,University , Italy.,67-86 .

Tracey ,B., Tews ,M.(1995).” Training Effectiveness: Accounting for Individual Characteristics and the Work Environment" Cornell University School of Hotel Administration ., 36(6), 36-42.

Tsutsui,K. and Fujiwara,M.( 2015), 'The Relationship between Positive Thinking and Individual Characteristics: Development of the Soccer Positive Thinking Scale"., Football Science Vol.12, 74-83

Trnka ,R and Parma,p .(2015)"'The Systemic Mind and a Conceptual Framework for the Psychosocial Environment of Business Enterprises: Practical Implications for Systemic Leadership Training” P,Sigmund Freud Universitats Verlag,

Truss,C., Gratton,L., Hailey,H,V., Mcgovern,P and Stiles,P.(1997)" Soft and Hard Models of Human Resource Management AReappraisal "CATHERINE Journal of Management Studies 34:1 .

Wilson,F,M.(2004),’Organizational Behavior and work: a critical introduction”, Great Britain.p155

Wellington, J. K. (2005)," The soft skills" of success: Be it high tech, low tech, or no tech", Vital Speeches of the Day, 71, 628.

Wong ,K,F., Pine ,R,J. and Tsang ,N.(2013),’Learning Style Preferences and Implications for Training Programs in the Hospitality and Tourism Industr",(vol)12,N( 2).,P $32-40$.

Zou ,M and Comp, B (2015),'Gender, work orientations and job satisfaction Min Bain \& Comp", Vol. 29(1) 3-22.
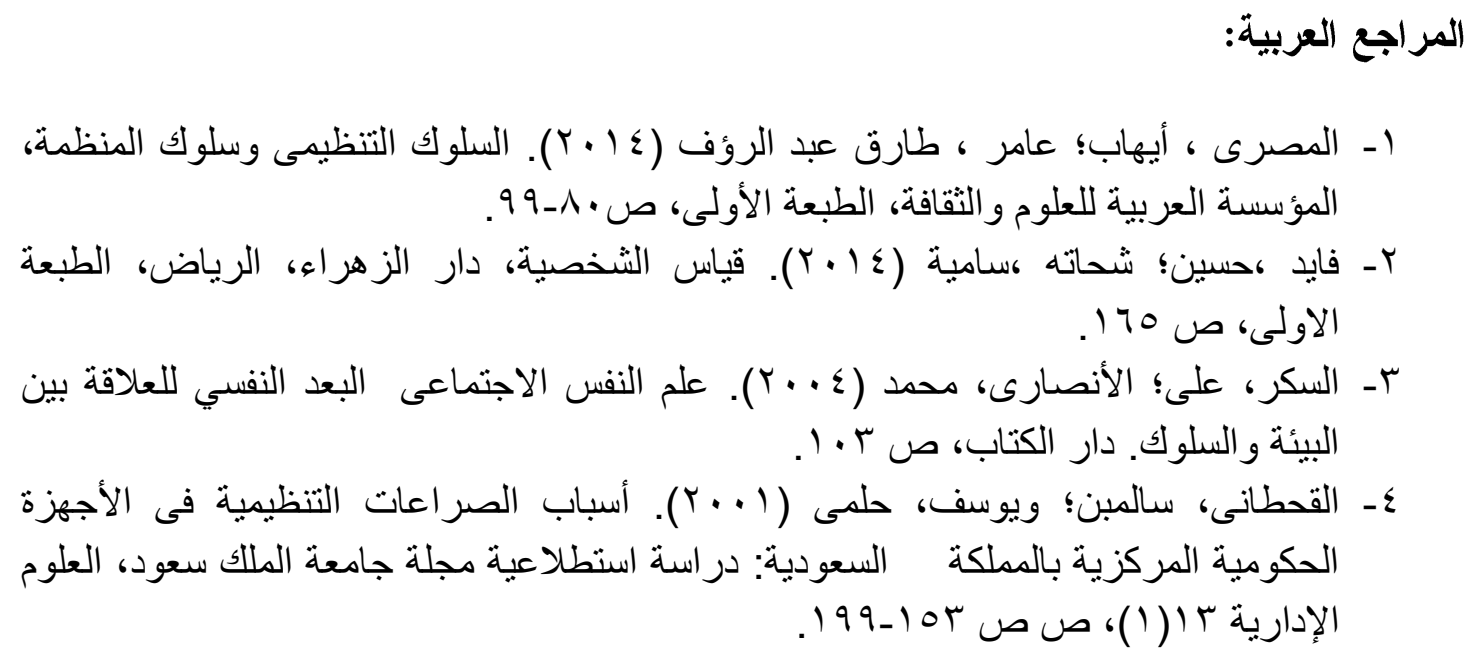
0ـ أبو النور، محمد و أحمد، سهير (ع ( + (Y). نظريات الثخصية، دار الزهراء، الرياض، ص

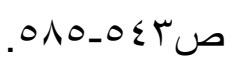

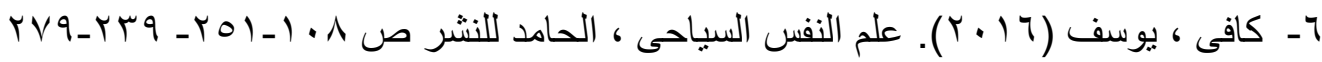

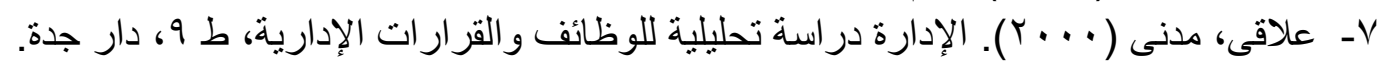
^- العيسوى ، عبد الرحمن محمد (T . . ץ)علم النفس السياحى ،كلية الآداب، جامعة الاسكندرية الدار الجامعية. 9 -

\title{
الملخص باللاغة العربية
}

التفكير الإيجابي كبرنامج تدريبي لتطوير بيئة العمل في صناعة الضيافة

\author{
الفاطمه فتح الله سلامة على الفي \\ قسم إدارة الفنادق كلية السياحة والفنادة سلامة على جامعة المنيا
}

يهدف هذا البحث إلى دراسة استر اتيجيات التواصل الإداري لإيجاد وسيلة عملية جديدة مثل احترام

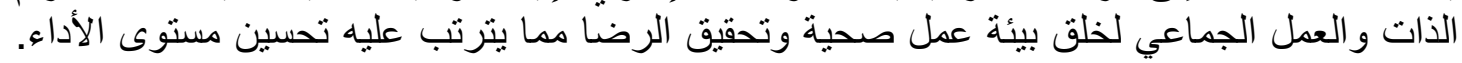

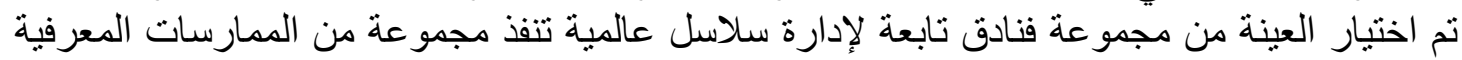

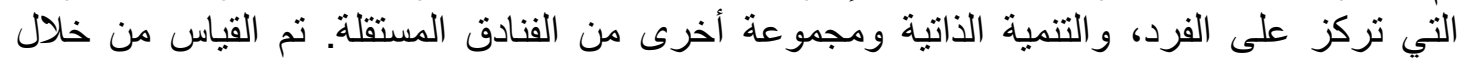

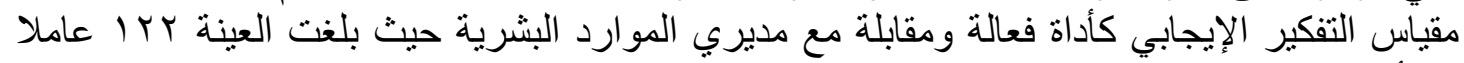

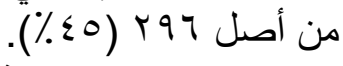

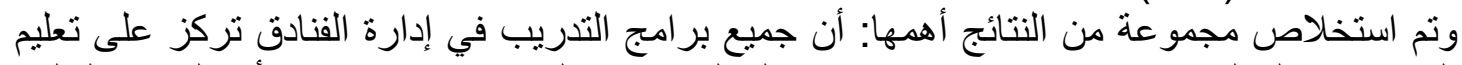

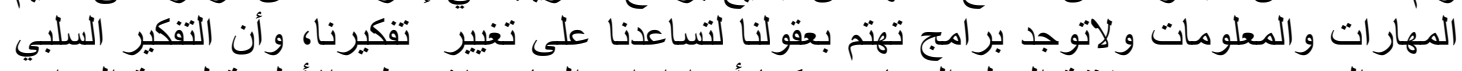

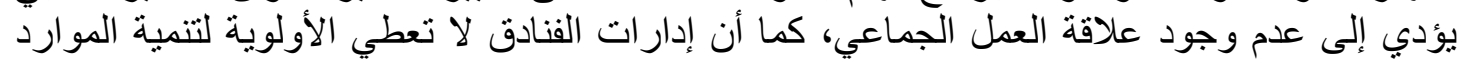
البشرية (التفكير الإيجابي) في بر امجها التدريبية لتنمية المهار ات النية الناعمة في ظلّ بيئة عمل صحية. 